\title{
Effect of Vegetable De Oiled Cake-Diesel Blends on Diesel Engine
}

\author{
C. Sundar Raj ${ }^{*}, 1$, A. Arivalagar ${ }^{2}$, S. Arul $^{3}$ and S. Sendilvelan ${ }^{2}$ \\ ${ }^{I}$ Dr. MGR Educational and Research Institute, Bharathiyar College of Engineering and Technology, Karaikal, India \\ ${ }^{2}$ Dr. MGR Educational and Research Institute, Dr. MGR University, Chennai, India \\ ${ }^{3}$ Panimalar College of Engineering, Chennai, India
}

\begin{abstract}
Alternative sources for petroleum fuels have been the prime concern of most of the environmentalists. It is also a concern for economists due to the depletable nature of the fossil fuel. Vegetable oils are considered as good alternatives to diesel as their properties are close to diesel. At present biodiesel is commercially produced from the vegetable oils by esterification processes. Since most of these oils are edible, its cost restricts the usage. The de oiled cakes after crushing the seeds contains around $2 \%$ of oil with less fatty materials is aimed in this study. The fuel is prepared by adding various dry de oiled cake powders (coconut, neem, ground nut and gingili) at different proportions ranging from 3 to $25 \%$ by weight with diesel. Experimental results reveal that, the fuel has the potential to reduce smoke, CO emissions simultaneously along with marginal increase in brake thermal efficiency. The combustion characteristic of each fuel is analysed and recorded.
\end{abstract}

Keywords: Vegetable de oiled cake powder, blended fuel, performance and emission characteristics and bio-fuels.

\section{INTRODUCTION}

The petroleum based diesel fuel needs to be substituted with alternate fuel to meet the energy demands in the future for developing countries. The fossil fuels are depleting drastically which increases the demand in the international market that affects the economy of the developing countries like India. Thus an alternate energy source has to be identified to overcome the problems with the petroleum based diesel fuel. One such energy source is fuel derived from vegetable oil that is bio diesel. Many bio diesels in the form of esters are being experimented to suit the diesel engine without any major engine modification. Pure coconut oil usage in diesel engine shows lesser smoke, carbon monoxide (CO), hydrocarbon ( $\mathrm{HC})$ emissions compared to diesel fuel since it has oxygen molecules which results in enhanced oxidation [1]. With pure coconut oil and diesel fuel blends in an automotive DI diesel engine increase in brake power and net heat release rate with a reduction in emissions such as $\mathrm{HC}, \mathrm{CO}, \mathrm{NOx}$, smoke are reported for coconut oil in the fuel blend. The increase in brake power is expected due to larger fuel droplets and oxygen content in coconut oil, which contribute to better combustion. When the coconut oil in the fuel is increased above $20 \%$ decrease in performance was reported which is attributed to lower calorific value, with a reduction in emissions [2]. Coconut oil methyl ester COME was investigated by a couple of authors in a variable speed DI diesel engine and their results show that COME gives maximum torque occurs at lower speed compared to diesel and the emissions are lowest for COME compared to diesel and pure coconut oil $[3,4]$. COME was compared with palm and rapeseed oil biodiesel and the results show that the

*Address correspondence to this author at the Dr. MGR Educational and Research Institute, Bharathiyar College of Engineering and Technology, Karaikal, India; E-mail: csundarraj@yahoo.com brake thermal efficiency was almost same whereas $\mathrm{HC}, \mathrm{CO}$, NOx and smoke emissions were lowest for COME compared to other fuels [5]. The fuel can be categorized as oxygenated fuel since it has oxygen molecules and this oxygen can enhance the oxidation during the combustion resulting in lesser $\mathrm{CO}, \mathrm{HC}$ and smoke emission [6-9]. Even though COME gives a significant reduction in emission, it is edible oil based fuel thus cost of the oil restricts its usage as a fuel for replacing diesel. Radu Rosca et al. [10] presented some experimental results concerning the use of a biodiesel type fuel (BTF) produced from waste cooking oil. They found that most of the physical properties of the methylester are close to or within the requirements of the international standards concerning biodiesel fuels and the use of methylester led to changes of the injection characteristics (increased injection pressure, lower average injection rate, and earlier start of combustion). Litrature review reveal that vegetable oil either directly or in the form of esters are used as alternate fuels in diesel engines and no attempt had been made so far with deoiled cake as fuel additive. The de oiled cakes contains oxygen with very minimum fatty substances and is available at very low cost, and hence in this work a fuel is produced by adding different proportions of de oiled cake with diesel and experiments were conducted to evaluate the performance, emission and combustion characteristics

\subsection{Fuel Preparation}

The major problems in direct use of vegetable oil as fuel in diesel engine are fuel filter plugging, choking of injector nozzles, sticking of piston rings and crankcase oil dilution. The kinematic viscosity of the vegetable oil is generally higher than diesel fuel and can be brought down by various techniques such as preheating, blending, emulsification and transesterification. The de oiled cakes of edible and non edible oils are good oxidizer having less fat and will be dissolved in diesel up to some extent. The de oiled cake was dried and pulverized and the 
fuel was prepared by adding known amount of pulverized de oiled cake with known amount of diesel and the blend is allowed to settle to get completely dissolved blend. The sediments are filtered and the fuel is used in diesel engine without any engine modification. The fuel thus prepared are tested and the properties are listed in Tables 1-4.

\subsection{Fuel Properties}

Table 1. Properties of Coconut De Oiled Cake Blends

\begin{tabular}{|c|c|c|c|c|c|c|c|}
\hline \multirow{2}{*}{ S. No } & \multirow{2}{*}{ Properties } & Diesel & \multicolumn{5}{|c|}{ Coconut Blends } \\
\cline { 4 - 8 } & & $\mathbf{5 \%}$ & $\mathbf{1 0 \%}$ & $\mathbf{1 5 \%}$ & $\mathbf{2 0 \%}$ & $\mathbf{2 5 \%}$ \\
\hline \hline 1 & Sp. gravity & 0.819 & 0.819 & 0.820 & 0.820 & 0.821 & 0.821 \\
\hline 2 & $\begin{array}{c}\text { Kinemetic } \\
\text { viscosity at } \\
40^{\circ} \mathrm{C}\end{array}$ & 3.366 & 3.422 & 3.457 & 3.561 & 3.830 & 3.891 \\
\hline 3 & $\begin{array}{c}\text { Calorific } \\
\text { value } \\
\mathrm{KJ} / \mathrm{Kg}\end{array}$ & 42000 & 40488 & 39297 & 38106 & 36415 & 35724 \\
\hline
\end{tabular}

Table 2. Properties of Gingili De Oiled Cake Blends

\begin{tabular}{|c|c|c|c|c|c|c|c|}
\hline \multirow{2}{*}{ S. No } & \multirow{2}{*}{ Properties } & \multirow{2}{*}{ Diesel } & \multicolumn{5}{|c|}{ Gingili Blends } \\
\cline { 4 - 8 } & & $\mathbf{5 \%}$ & $\mathbf{1 0 \%}$ & $\mathbf{1 5 \%}$ & $\mathbf{2 0 \%}$ & $\mathbf{2 5 \%}$ \\
\hline \hline 1 & Sp. gravity & 0.819 & 0.819 & 0.819 & 0.819 & 0.820 & 0.820 \\
\hline 2 & $\begin{array}{c}\text { Kinemetic } \\
\text { viscosity } \\
\text { at } 40^{\circ} \mathrm{C}\end{array}$ & 3.366 & 3.39 & 3.40 & 3.46 & 3.58 & 3.76 \\
\hline 3 & $\begin{array}{c}\text { Calorific } \\
\text { value } \\
\text { KJ/Kg }\end{array}$ & 42000 & 40488 & 38106 & 36915 & 35874 & 35724 \\
\hline
\end{tabular}

Table 3. Properties of Groundnut De Oiled Cake Blends

\begin{tabular}{|c|c|c|c|c|c|c|c|}
\hline \multirow{2}{*}{ S. No } & \multirow{2}{*}{ Properties } & Diesel & \multicolumn{5}{|c|}{ Ground Nut Blends } \\
\cline { 4 - 8 } & & $\mathbf{5 \%}$ & $\mathbf{1 0 \%}$ & $\mathbf{1 5 \%}$ & $\mathbf{2 0 \%}$ & $\mathbf{2 5 \%}$ \\
\hline \hline 1 & Sp. gravity & 0.819 & 0.819 & 0.819 & 0.819 & 0.820 & 0.820 \\
\hline 2 & $\begin{array}{c}\text { Kinemetic } \\
\text { viscosity } \\
\text { at } 40^{\circ} \mathrm{C}\end{array}$ & 3.366 & 3.39 & 3.40 & 3.46 & 3.58 & 3.76 \\
\hline 3 & $\begin{array}{c}\text { Calorific } \\
\text { value } \\
\mathrm{kJ} / \mathrm{kg}\end{array}$ & 42000 & 39297 & 38106 & 36915 & 35850 & 35724 \\
\hline
\end{tabular}

Table 4. Properties of Neem De Oiled Cake Blends

\begin{tabular}{|c|c|c|c|c|c|c|c|}
\hline \multirow{2}{*}{ S. No } & \multirow{2}{*}{ Properties } & Diesel & \multicolumn{5}{|c|}{ Neem Blends } \\
\cline { 4 - 8 } & & $\mathbf{5 \%}$ & $\mathbf{1 0 \%}$ & $\mathbf{1 5 \%}$ & $\mathbf{2 0 \%}$ & $\mathbf{2 5 \%}$ \\
\hline \hline 1 & Sp. gravity & 0.819 & 0.819 & 0.819 & 0.820 & 0.820 & 0.820 \\
\hline 2 & $\begin{array}{c}\text { Kinemetic } \\
\text { viscosity } \\
\text { at } 40^{\circ}\end{array}$ & 3.366 & 3.37 & 3.48 & 3.507 & 3.64 & 3.67 \\
\hline & $\begin{array}{c}\text { Calorific } \\
\text { value } \\
\mathrm{KJ} / \mathrm{Kg}\end{array}$ & 42000 & 40485 & 39297 & 38106 & 36415 & 35724 \\
\hline
\end{tabular}

\section{EXPERIMENTAL SETUP AND TEST PROCEDURE}

Experiment were conducted on kirloskar TV1, four stroke, single cylinder, air cooled diesel engine. The rated power of the engine was $5.2 \mathrm{kw}$ at $1500 \mathrm{rpm}$. The engine was operated at a constant speed of $1500 \mathrm{rpm}$ and standard injection pressure of 200 bar pressure. The fuel flow rate was measured on volume basis using a burette and a stop watch. K-type thermocouple and a digital display were employed to note the exhaust gas temperature. AVL smoke meter was used for measurement of smoke density. NOx emission was measured by AVL five gas analyzer. In cylinder pressure was measured with help of AVL combustion analyzer. Experiments were conducted with five different blends of diesel with various de oiled cake powder ranging from 5 to $25 \%$ by weight to sole fuel. The schematic experimental setup is shown in Fig. (1). Readings were taken, when the engine was operated at a constant speed of $1500 \mathrm{rpm}$ for all loads. Parameter like engine speed, fuel flow and the emission characteristics like NOx and smoke were recorded. The performance of the engine was evaluated in terms of brake thermal efficiency, brake power, specific fuel consumption from the above parameters. The combustion characteristics like cylinder pressure and heat release rate were noted for different blends.

\section{RESULTS AND DISCUSSION}

Performance analysis of various fuel blends at different load conditions were performed to find the optimum blend ratio. Emission tests were conducted for the optimum blend of each type and the results are discussed. The variation of brake thermal efficiency for different blends of de oiled cake powder of Coconut, Neem and Gingili at 50\% load is shown in Fig. (2). It is observed that each blend increases the brake thermal efficiency due to the presence of oxygen in the fuel. But decrease in the heat value of the mixture reduces the efficiency for higher blend ratio. It is observed that CDOCP, GNDOCP, NDOCP records maximum efficiency for $15 \%$ blend and GINDOCP for $10 \%$ blend and hence they were taken as optimum blends. $2 \%$ increase in brake thermal efficiency observed for CDOCP and NDOCP blends and it is $1 \%$ for GNDOCP, $1.5 \%$ for GINDOCP compared with the sole fuel. The oxygen molecules present in the fuel enhances the combustion resulting in higher thermal efficiency.

Fig. (3) shows the variation of pressure with respect to crank position. The maximum pressure is obtained for diesel and all blends at 6 degrees after TDC implies that there is no change in the delay period. The close view of Fig. (3) shown in Fig. (4) imply that de oiled cake addition reduces the maximum cylinder pressure. Even though the presence of oxygen improves the combustion the increase in molecular weight may be the reason for this decrease in pressure. The maximum pressure obtained is 77.736 bar and it is 76.627 bar for 15\% CDOCP, 74.783 bar for 15\%GNDOCP, 76.542 bar for $15 \%$ GINDOCP and 76.627 bar for $10 \%$ NDOCP blends. CDOCP blends having closer value to diesel.

The heat release rate for diesel and various blends is illustrated in Fig. (5). It can be seen that heat release rate curves of the oxygenated fuel blends and sole fuel shows similar curve pattern although the rate of heat release is slightly reduced for de oiled cake blended fuels. The reason 


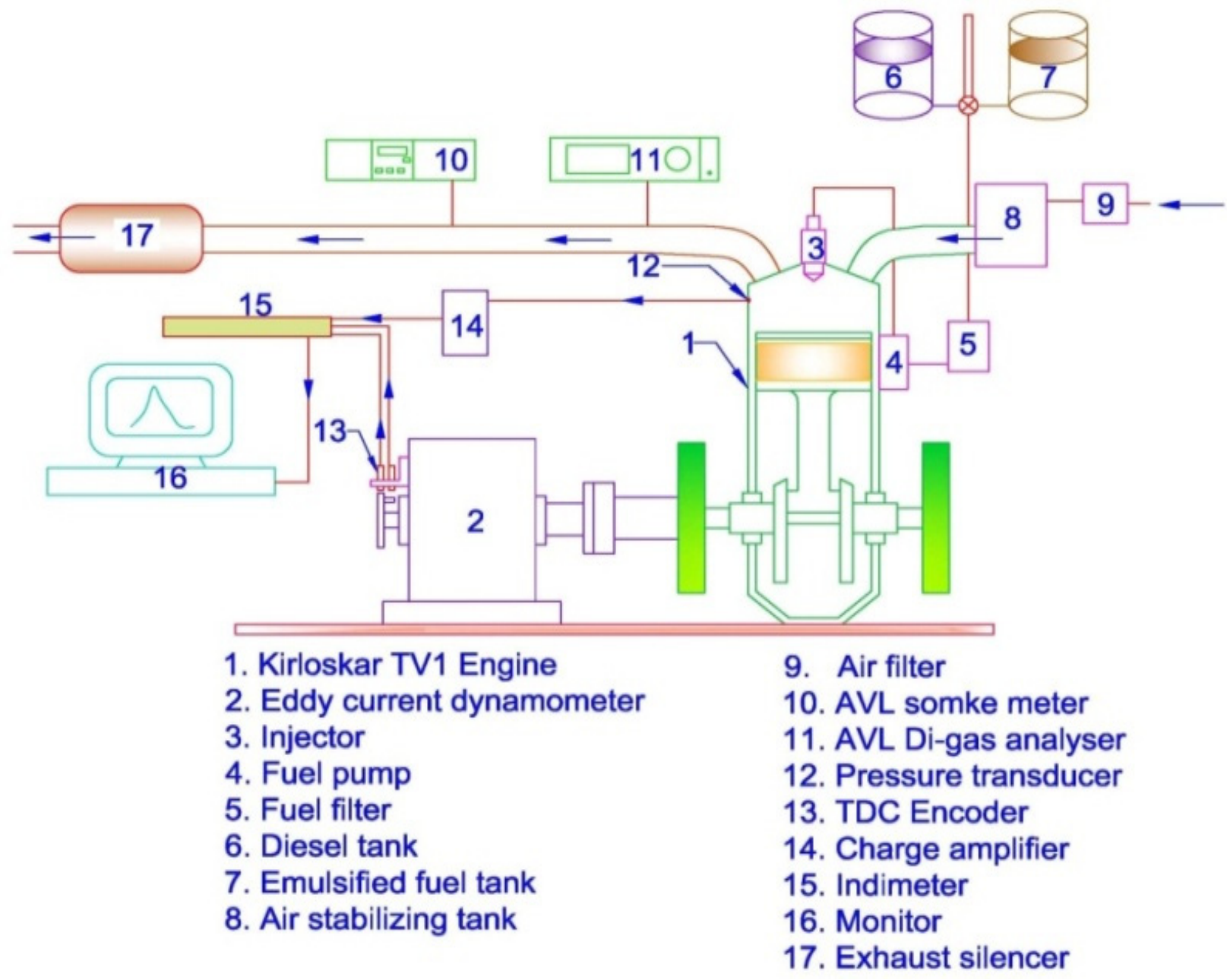

Fig. (1). Experimental setup.

is the rate of diffusion combustion of the blended fuel is decreased due to the change in molecular weight of the fuel. It is also observed that the maximum heat release rate is at 5 degrees before TDC. It is $103 \mathrm{KJ} / \mathrm{m} 3$ degree for diesel and varies from 95 to 102 for other oil blends. It is also observed that the heat release rate after -5 degrees is highly reduced for blends than the pure diesel as the combustion completes before TDC due to the presence of oxygen molecules.

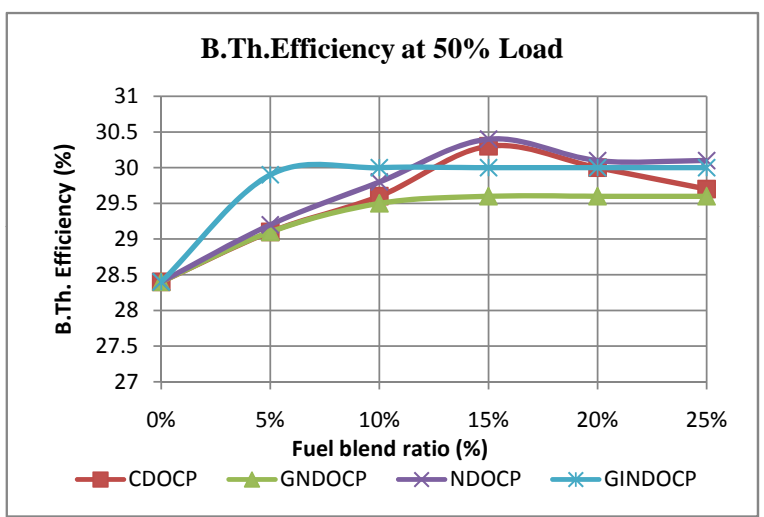

Fig. (2). Variation of brake thermal efficiency for de oiled cake blends.

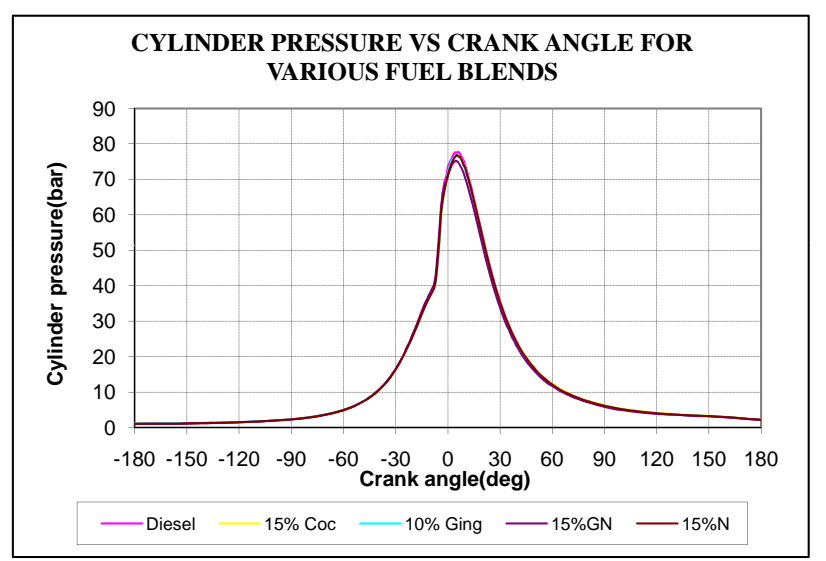

Fig. (3). Pressure variation with crank angle.

The variation of NOx with load for neat diesel and blends are shown in Fig. (6). There is no variation in NOx emission up to $50 \%$ of load for all blends and it increases with load. Temperature is one of the major factors for NOx formation when, the peak combustion temperature increases $\mathrm{NOx}$ emission increases. Improvement in combustion due to the presence of oxygen may be the reason for the increase in NOx emission at part and peak load condition. The maximum increase was found to be $26 \%$. 


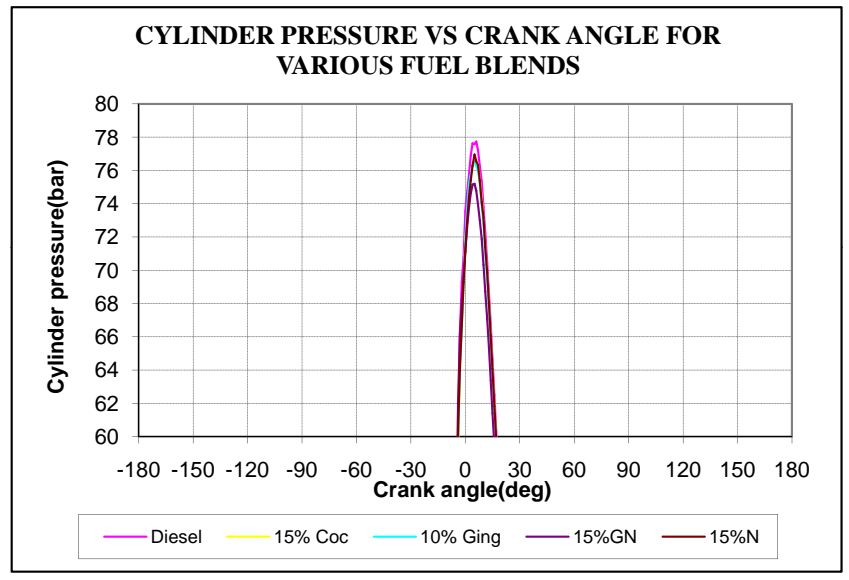

Fig. (4). Closure view of pressure change with crank angle.

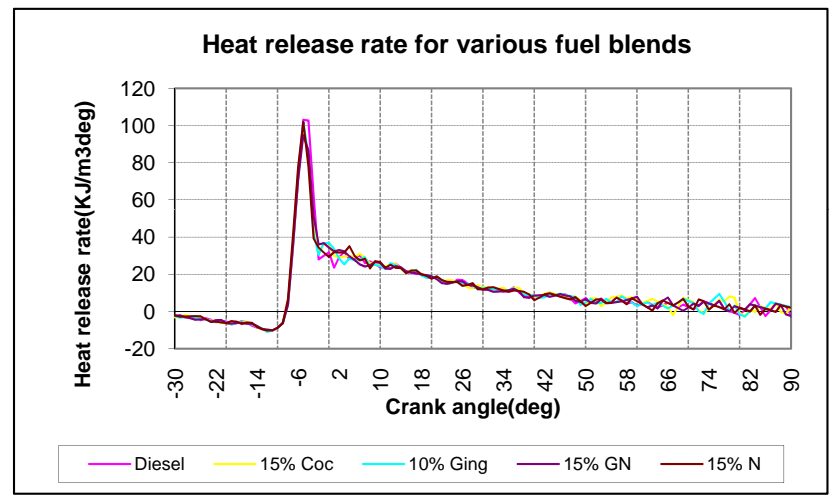

Fig. (5). Heat release rate with crank angle.

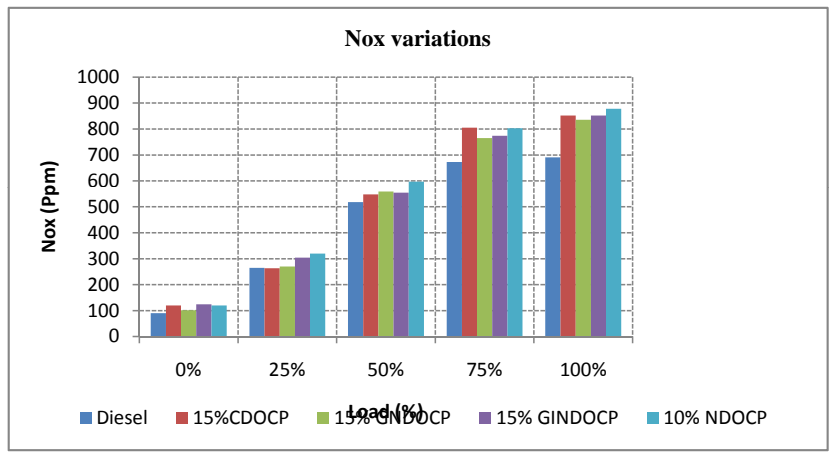

Fig. (6). Nox emission reduction.

Smoke density gets reduced for all blends as the combustion completes before TDC. Fig. (7) shows the smoke reduction rate for various blends. CDOCP and GINDOCP reduce the smoke at all operating conditions than the other blends. The results reveal that the tendency to generate soot from the fuel-rich regions inside diesel diffusion combustion zone is decreased by the oxygen present in the de oiled cake.

The CO emission for all fuel blends was decreased while the engine gets loaded. The maximum reduction was $33 \%$ at full load for all blends as shown in Fig. (8). Complete combustion due to the presence of oxygen molecules in the fuel is the reason for this reduction.

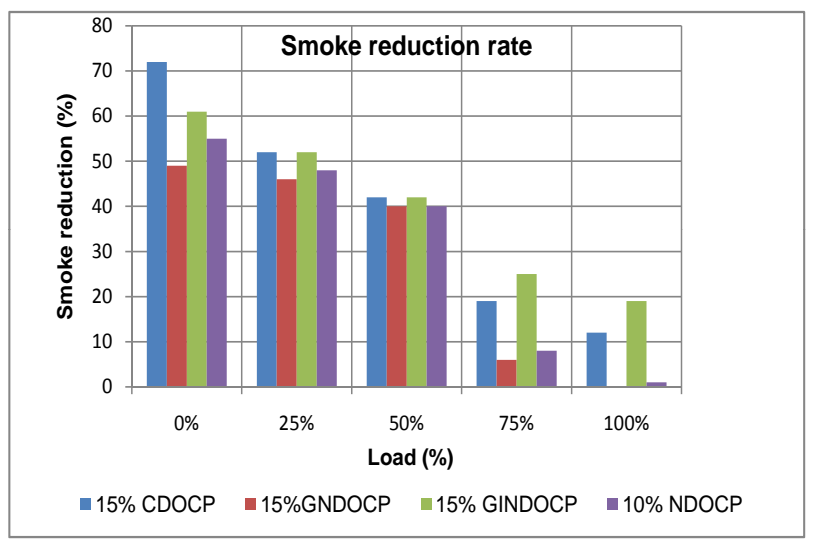

Fig. (7). Smoke.

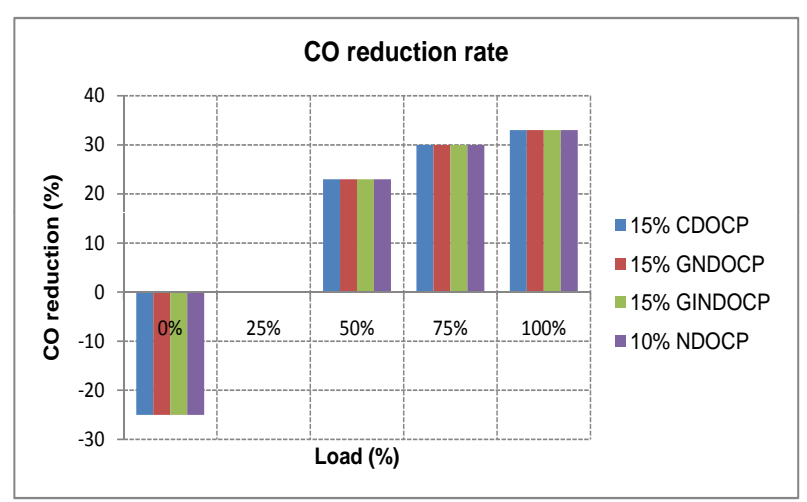

Fig. (8). CO emission reduction rate rate.

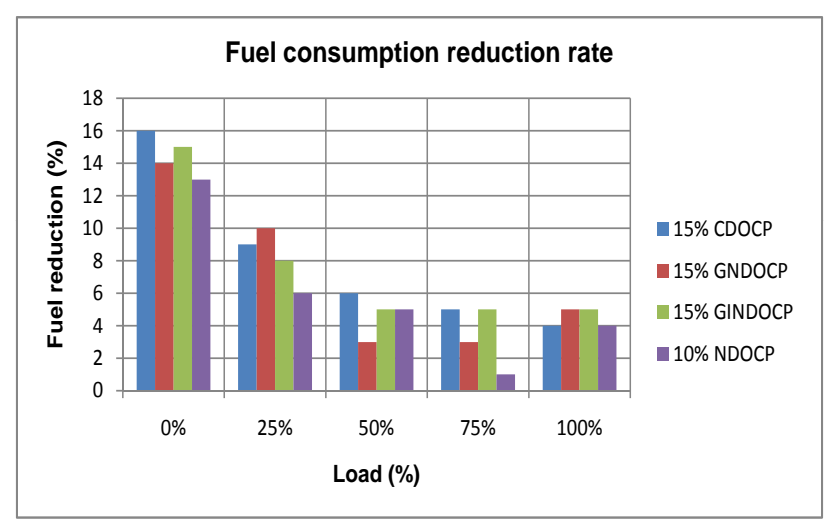

Fig. (9). Fuel consumption reduction. 
Fig. (9) indicates that the fossil oil consumption is reduced by 14 to $15 \%$ at low loads and 4 to $5 \%$ at peak loads by de oiled bio diesel.

\section{CONCLUSION}

The major conclusions drawn from the experiments were as follows:

- $\quad$ The brake thermal efficiency for all de oiled cake blends is higher than neat diesel fuel operation. CDOCP and NDOCP gave better performance than the other blends

- $\quad$ The maximum cylinder pressure is at 6 degrees after TDC for neat diesel and other blends. CDOCP and NDOCP gave closer value to neat diesel.

- $\quad$ Since the maximum pressure occurred at the same position of crank for all fuels there is no need for engine modification.

- $\quad$ The maximum heat release is 5 degrees before TDC for all fuels and as the rate decreases uniformly the fuel blends does not results in knock

- $\quad$ The oxides of nitrogen (NOx) increases with load for all blends.

- $\quad$ The smoke is considerably reduced for de oiled cake blends.

- $\quad \mathrm{CO}$ emission is considerably reduced at medium and at high loads.

- $\quad 15 \%$ CDOCP blend was found optimum in all cases

On the whole it is concluded that de oiled cake powders may be used as an oxygenated additive with diesel to improvements in performance and emissions of a diesel engine.

\section{NOMENCLATURE}

$\begin{array}{ll}\text { CDOCP } & =\text { Coconut de oiled cake powder } \\ \text { Coc } & =\text { Coconut } \\ \text { COME } & =\text { Coconut oil methyl ester }\end{array}$

$\begin{array}{ll}\text { GINDOCP } & \text { Gingili de oiled cake powder } \\ \text { Ging } & =\text { Gingili } \\ \text { GN } & =\text { Ground nut } \\ \text { GNDOCP } & =\text { Ground nut de oiled cake powder } \\ \mathrm{N} & =\text { Neem } \\ \text { NDOCP } & =\text { Neem de oiled cake powder }\end{array}$

REFERENCES

[1] Herchel, T. C.; Machacon,; Seiichi Shiga,; TakaoKarasawa,; Hisao Nakamura. Performance and emission characteristics of a diesel engine fuelled with coconutoil - diesel fuel blend. Biomass Bioenergy, 2001, 20, 63-69.

[2] Kalam, M.A.; Husnawan, M.; Masjuki, H.H. Exhaust emissions and combustion evaluation of coconut oil - powered indirect injection diesel engine. Renewable Energy, 2003, 28, 2405 - 2415.

[3] Shaeed, A.; Swain, E. Combustion analysis of coconut oil and its methyl esters in diesel engine. IMechE Proc. Inst. Mech. Eng. Part$A, \mathbf{1 9 9 9}, 213,417-425$.

[4] Masjuki, H.H.; Kalam, M.A.; Maleque, M.; Kubo, A.; Nonaka, T. Performance, emission and wear characteristics of an indirect injection diesel engine using coconut oil blended fuel. IMechE Proc. Inst. Mech. Eng. Part D, 2001, 215, 393-404.

[5] Kinoshita, E.; Myo, T.; Hamasaki, K.;Tajima, H.; Kun, Z.R. Diesel combustion characteristics of coconut oil and palm oil biodiesels, 2006, SAE international, 2006-01-3251.

[6] Ronald J. Donahue,; David E. Foster. Effects of oxygen enhancement on the emissions from a DI diesel via manipulation of fuels and combustion chamber gas composition, 2000, SAE International, 2000-01-0512.

[7] David L. Hilden; John C. Eckstrom; Leslie R. Wolf. The emissions performance of oxygenated diesel fuels in a prototype DI diesel engine, 2001, SAE International, 2001-01-0650.

[8] Mitosuo Tamanouchi,;Hiroki Morihisa,; Shigehisa Yamada. Effects of fuel properties on exhaust emissions for diesel engines with and without oxidation catalyst and high pressure injection, 1997, $S A E$ international 970758.

[9] Ravikadiyala, B.; Apparao, V. Some comparative performance studies on DI diesel engine with pungam methyl ester and diesel oil. Proceedings of the $19^{\text {th }}$ National Conference on IC Engine and Combustion, 2005, pp. 47-54.

[10] Rosca. R.; Rakosi, E.; Manolache, G.; Niculaua, M. Fuel and Injection Characteristics for a Biodiesel Type Fuel from Waste Cooking Oil, 2005, SAE International, 2005- 01-3674. 